\title{
IMPLEMENTASI STRATEGI PEMBELAJARAN KONTEKSTUAL DI MI (MADRASAH IBTIDAIYAH)
}

\author{
${ }^{1)}$ Much Mahfud Arif, email : muchmahfudarif@stitmatuban.ac.id \\ ${ }^{2)}$ Rr.Kusuma Dwi Nur Ma’rifati, email : rrkusumadewi@stitmatuban.ac.id
}

\begin{abstract}
Learning is essentially a process of interaction between students and their environment, so there is a change in behavior to be better. In learning, the most important task of the teacher is to condition the environment so that it supports behavior change for students. The use of appropriate learning strategies will also determine the effectiveness and efficiency of learning. Learning needs to be done with fewer lectures and teacher-centered methods, and more emphasis on student interaction. The use of a variety of strategies will greatly assist students in achieving learning objectives. One good learning strategy is contextual learning strategy. Because contextual learning strategies can combine three aspects of intelligence, including cognitive, affective and psychomotor aspects. Contextual learning strategies can provide space for students to be directly involved in the learning process. So students are no longer seen as objects, but subjects who can show their existence and contribution in education. Contextual learning and teaching involve students in important activities that help them relate academic learning and the real life contexts they face. By linking the two, students see the meaning in schoolwork. Fiqh subjects in madrasah ibtidaiyah with a contextual learning strategy approach provide opportunities for students to explore cognitive abilities in implementing material in the process of teaching and learning activities more innovative and comprehensive.
\end{abstract}

Keywords : Contextual learning strategy, Implementation strategy, Fiqh subjects

\section{Pendahuluan}

Pembelajaran pada hakekatnya adalah proses interaksi antara peserta didik dengan lingkunganya, sehingga terjadi perubahan perilaku kearah yang lebih baik. ${ }^{1}$ Dalam pembelajaran, tugas guru yang paling utama adalah mengkondisikan lingkungan agar menunjang terjadinya perubahan perilaku bagi peserta didik. Seorang guru harus menyadari bahwa mengajar memiliki sifat yang kompleks karena melibatkan aspek pedagogis, psikologis, dan didaktis secara kebersamaa. $^{2}$ Tugas guru dalam pembelajaran tidak terbatas pada penyampaian informasi kepada

\footnotetext{
1. E. Mulyasa, Kurikulum Tingkat Satuan Pendidikan, (Bandung: PT Remaja Rosdakarya, 2007) Hlm. 255.

2. E. Mulyasa, Menjadi Guru Profesional (Menciptakan Pembelajaran Kreatif dan menyenangkan), (Bandung: PT Remaja Rosdakarya, 2005) Hlm, 20.
} 
peserta didik. Sesuia kemajuan dan tuntunan zaman, guru harus memiliki kemampuan untuk memahami peserta didik dengan berbagai keunikanya agar mampu membantu mereka dalam menghadapi kesulitan belajar. Dalam hal itu, guru dituntut memahami berbagai model pembelajaran yang efektif agar dapat membimbing peserta didik secara optimal.

Penggunaan strategi pembelajaran yang tepat akan turut menentukan efektivitas dan efesiensi pembelajaran. Pembelajaran perlu dilakukan dengan sedikit ceramah dan metodemetode yang berpusat pada guru, serta lebih menekankan pada interaksi peserta didik. Penggunaan strategi yang bervariasi akan sangat membantu peserta didik dalam mencapai tujuan pembelajaran. Salah satu strategi pembelajaran yang baik adalah strategi pembelajaran kontekstual. Karena strategi pembelajaran kontekstual dapat memadukan antara tiga aspek kecerdasan, antara lain aspek kognitif, afektif dan psikomotorik. Strategi pembelajaran kontekstual dapat memberikan ruang kepada peserta didik untuk terlibat secara langsung dalam proses pembelajaran. Sehingga peserta didik tidak lagi dipandang sebagai objek, akan tetapi subjek yang dapat menunjukkan eksistensi dan konstribusinya dalam pendidikan.

Permasalahan terbesar yang dihadapi para peserta didik sekarang (siswa) adalah mereka belum bisa menghubungkan antara apa yang mereka pelajari dan bagaimana pengetahuan itu akan digunakan dalam realita yang ada. Hal ini dikarenakan cara mereka memperoleh dan mengolah informasi dan motivasi diri belum tersentuh oleh metode yang betul-betul bisa membantu mereka. Oleh karena itu, diperlukan suatu metode yang benar-benar bisa memberi jawaban dari masalah ini. Salah satu metode yang bisa lebih memberdayakan siswa adalah pendekatan kontekstual (Contextual Teaching and Learning/CTL).

Pembelajaran dan pengajaran kontekstual melibatkan para siswa dalam aktifitas penting yang membantu mereka mengaitkan pelajaran akademis dan konteks kehidupan nyata yang mereka hadapi. ${ }^{3}$ Dengan mengkaitkan keduanya , para siswa melihat makna di dalam tugas sekolah. Mata pelajaran fikih di madrasah ibtidayah dengan pendekatan strategi pembelajaran kontekstual memberikan kesempatan kepada siswa untuk mengeksplorasi kemampuan koginif, afektif dan psikomotornya dalam mengimplementasikan materi dalam proses kegiatan belajar mengajar lebih inovatif dan komprehensif. Strategi pembelajaran yang baik dan menyenangkan, akan dapat juga menciptakan suasana yang kondusif dalam proses pembelajaran. Tanpa adanya

\footnotetext{
${ }^{3}$. Elaine B. Johnson, Contextual Teaching \& Learning (Menjadikan Kegiatan Belajar-Mengajar Mengasikkan dan Bermakna),Terj. Ibnu Setiawan (Bandung : Penerbit MLC, 2007) Hlm. 35.
} 
suasana kondusif, maka proses pembelajaran akan mendapatkan suatu hambatan di dalam pelaksanaannya. Karena hal tersebut memiliki pengaruh terhadap keberhasilan suatu pendidikan. oleh karena itu, dengan adanya strategi pembelajaran yang baik tersebut, diharapkan dapat menciptakan peserta didik yang memiliki kreatifitas dan inovatif dalam melakukan aktualisasi dari gagasan-gagasan yang dimilikinya.

\section{Kajian Teori}

\section{Pengertian Strategi Pembelajaran Kontekstual}

Pengajaran dan pembelajaran kontekstual adalah merupakan model pembelajaran yang mengkaitkan antara materi pembelajaran dengan situasi dunia nyata yang berkembang dan terjadi di lingkuangan sekitar peserta didik sehingga dia mampu menghubungkan dan menerapkan kompetensi hasil belajar dengan kehidupan sehari-hari mereka. ${ }^{4}$ Dengan demikian pembelajaran kontekstual merupakan konsep belajar dan mengajar yang membantu guru mengkaitkan antara materi yang diajarkanya dengan situasi dunia nyata siswa dan mendorong siswa membuat hubungan antara pengetahuan yang dimilikinya dengan penerapannya dalam kehidupan mereka sebagai anggota keluarga, warga Negara dan pekerja. ${ }^{5}$

Menurut Johnson pembelajaran kontekstual berarti memungkinkan siswa menghubungkan isi materi dengan konteks kehidupan sehari-hari untuk menemukan makna. ${ }^{6}$ Pembelajaran kontektual dapat dikatakan sebagai sebuah pendekatan pembelajaran yang mengakui dan menunjukkan kondisi alamiah dari pengetahuan. ${ }^{7}$ Melalui hubungan di dalam dan di luar kelas, suatu pendekatan pembelajaran kontekstual menjadikan pengalaman lebih relevan dan berarti bagi siswa dalam membangun pengetahuan yang akan mereka terapkan dalam pembelajaran seumur hidup. Pembelajaran menyajikan suatu konsep yang mengkaitkan materi pelajaran yang dipelajari siswa dengan konteks di mana materi pelajaran yang dipelajari siswa dengan konteks di mana materi tersebut digunakan, serta berhubungan dengan bagaimana seseorang belajar atau gaya/ cara siswa belajar. Konteks memberikan arti, relevansi dan manfaat terhadap belajar.

\footnotetext{
${ }^{4}$. Khaeruddin dan Mahfud Junaedi, Kurikulum Tingkat Satuan Pendidikan (Konsep dan Implementasinya di Madrasah), (Yogyakarta : PILAR MEDIA, 2007) Hlm. 199.

5. Kokom Komalasari, Pembelajaran Kontekstual: Konsep dan Aplikasi,(Bandung : PT Refika Aditama, 2010) Hlm, 6.

6. Ibid, Hlm, 6 .

7. Trianto, Mendesain Model Pembelajaran Inovatif-Progresif : Konsep, Landasan, dan Implementasinya Pada Kurikulum Tingkat Satuan Pendidikan (KTSP), (Jakarta : Prenada Media Group, 2010), Hlm. 107.
} 
Hal ini menunjukkan bahwa di dalam pembelajaran kontekstual, siswa menemukan hubungan penuh makan antara ide-ide abstrak dengan penerapan praktis di dalam kontek dunia nyata. Siswa menginternalisasi konsep melaui penemuan, penguatan, dan keterhubungan. Pembelajaran kontekstual menghendaki kerja dalam sebuah tim, baik di kelas maupun laboratorium. Pembelajaran kontekstual menuntut guru mendesain lingkungan belajar yang merupakan gabungan beberapa bentuk pengalaman untuk mencapai hasil yang diinginkan.

2. Karakteristik Pembelajaran Kontekstual

Menurut Johnson yang dikutip Kokom mengidentifikasi delapan karakteristik pengajaran dan pembelajaran kontekstual, yaitu : ${ }^{8}$

a. Making meaningful connections ( membuat hubungan penuh makna)

Siswa dapat mengatur diri sendiri sebagai orang yang belajar aktif dalam mengembangkan minatnya secara individual, orang yang dapat bekerja sendiri atau bekerja dalam kelompok, dan orang yang dapat belajar sambil berbuat (learning by doing).

b. Doing significant work (melakukan pekerjaan penting)

Siswa membuat hubungan-hubungan antara sekolah dan berbagai konteks yang ada dalam kehidupan nyata sebagai anggota masnyarakat.

c. Self- regulated learning (belajar mengatur sendiri)

Siswa melakukan pekerjaan signifikan: ada tujuanya, ada urusanya dengan orang lain, ada hubunganya dengan penentuan pilihan, dan ada produk/hasilnya yang bersifat nyata.

\section{d. Collaborating (kerjasama)}

Siswa dapat bekerja sama. Guru membantu bekerja secara efektif dalam kelompok, membantu mereka memahami bagaimana mereka saling memengaruhi dan saling berkomunikasi.

e. Critical and creative thinking ( berfikir kritis dan kreatif )

Siswa dapat menggunakan tingkat berfikir yang lebih tinggi secara kritis dan kreatif: dapat menganalisis, membuat sistesis, memecahkan masalah, membuat keputusan, dan menggunakan bukti-bukti dan logika.

\footnotetext{
8. Kokom Komalasari, Pembelajaran Kontekstual, ,....... Hlm.7-8
} 


\section{f. Nurturing the individual (memelihara individu)}

Siswa memelihara pribadinya: mengetahui, memberi perhatian, memberi harapan-harapan yang tinggi, memotivasi dan memperkuat diri sendiri. Siswa tidak dapat berhasil tanpa dukungan orang dewasa.

g. Reaching high standards ( mencapai standar tinggi)

Siswa mengenal dan mencapai standar yang tinggi: mengidentifikasi tujuan dan motivasi siswa untuk mencapainya. Guru memperlihatkan kepada siswa cara mencapai apa yang disebut "excellence".

h. Using authentic assessement ( menggunakan penilaian yang otentik)

Siswa menggunakan pengetahuan akademis dalam konteks dunia nyata untuk suatu tujuan yang bermakana. Misalnya, siswa boleh menggambarkan infomasi akademis yang telah mereka pelajari untuk diaplikasikan dalam kehidupan nyata.

Adapun prinsip yang penting dalam pendekatan pembelajaran kontekstual dalam pengaplikasianya antara lain adalah $:^{9}$

a. keterkaitan (relating)

Dalam hal ini guru menggunakan strategi relating ini apabila ia mengkaitkan konsep baru dengan sesuatu yang sudah dikenal siswa. Jelasnya, mengkaitkan apa yang sudah diketahui siswa dengan informasi baru.

b. Pengalaman langsung (experiencing)

Merupakan inti pembelajaran kontekstual dimana mengkaitkan berarti menghubungkan informasi baru dengan pengalaman maupun pengetahuan informasi baru dengan pengalaman sebelumnya. Pembelajaran bisa terjadi dengan lebih cepat ketika siswa memanfaatkan (memanipulasi) peralatan dan bahan serta melakukan bentuk-bentuk penelitian yang aktif.

c. Aplikasi (applying)

Ketika siswa menerapkan konsep dalam aktivitas belajar memecahkan masalahnya, guru dapat memotivasi siswa dengan memberikan latihan yang realistik dan relevan.

d. Kerja sama (cooperating)

Pembelajaran yang menerapkan konsep kerja sama adalah pembelajaran yang mendorong kerjasama antar siswa, antara siswa dengan guru dan sumber belajar.

\footnotetext{
${ }^{9}$. http://organisasi.org/strategi-pembelajaran-kontekstual-oleh-oleh-dari-plpg-slamet-p Diakses Pada Tanggal 20 Desember 2019.
} 


\section{e. Alih pengetahuan (transferring)}

Fungsi dan peran guru dalam konteks ini adalah menciptakan bermacam-macam pengalaman belajar dengan fokus pada pemahaman bukan hafalan.

\section{Asas-Asas Strategi Pembelajaran Kontekstual}

Strategi pembelajaran kontekstual sebagai suatu pendekatan pembelajaran memiliki 7 asasasas yang melandasi pelaksanaannya dengan menggunakan pendekatan CTL. Sering kali asas ini disebut juga dengan komponen-komponen CTL, di antaranya:

a. Konstruktivisme

Pembelajaran kontekstual mendasarkan pada filosofi konstruktivisme. Konstruktivisme adalah salah satu filasafat pengetahuan yang menekankan bahwa pengetahuan kita adalah konstruksi (bentukan) kita sendiri. ${ }^{10}$ pendekatan ini pada dasarnya menekankan pentingnya siswa membangun sendiri pengetahuan mereka lewat keterlibatan aktif proses belajar mengajar. ${ }^{11}$

Asumsi itu yang kemudian melandasi CTL. Pembelajaran melalui CTL pada dasarnya mendorong agar siswa bisa mengkonstruksi pengetahuannya melalui proses pengamatan dan pengalaman. Atas dasar asumsi tersebutlah, maka penerapan asas konstruktivisme dalam pembelajaran CTL, siswa didorong untuk mampu mengkonstruksi pengetahuan sendiri melalui pengalaman nyata.

b. Inkuiri (penyelidikan)

Inkuiri merupakan asas dalam pembelajaran CTL, dalam artian proses pembelajaran didasarkan pada pencarian dan penemuan melalui proses berpikir secara sistematis. Pengetahuan bukanlah sejuta fakta hasil dari mengingat, akan tetapi hasil dari proses menemukan sendiri. Dengan demikan dalam proses perencanaan, guru bukanlah mempersiapkan sejumlah materi yang harus dihafal, akan tetapi merancang pembelajaran yang memungkinkan siswa dapat menemukan sendiri materi yang harus dipahaminya. Belajar pada dasarnya merupakan proses mental seseorang yang tidak terjadi secara mekanis. Secara umum proses inkuiri dapat dilakukan melalui beberapa langkah, yaitu;
a) Merumuskan masalah.
b) Mengajukan hipotesa.

\footnotetext{
${ }^{10}$. Kokom komalasari, Pembelajaran Kontekstual, ........., Hlm, 15.

${ }^{11}$. Trianto, Mendesain Model Pembelajaran, ............ Hlm. 111.
} 
c) Mengumpulkan data.

d) Menguji hipotesa berdasarkan data yang ditemukan.

e) Membuat kesimpulan. ${ }^{12}$

c. Bertanya (Questioning)

Belajar pada hakikatnya adalah bertanya dan mejawab pertanyaan. Bertanya dapat dipandang sebagai refleksi dari keingintahuan setiap individu, sedangkan menjawab pertanyaan mencerminkan kemampuan seseorang dalam berpikir. Dalam proses pembelajaran melalui CTL, guru tidak menyampaikan informasi begitu saja, akan tetapi memancing agar siswa dapat menemukan sendiri. Karena itu peran bertanya sangat penting, sebab melalui pertanyaan-pertanyaan guru dapat membimbing dan mengarahkan siswa untuk menemukan setiap materi yang dipelajarinya.

Dalam suatu pembelajaran yang produktif kegiatan bertanya akan sangat berguna untuk:

a) Menggali informasi tentang kemampuan siswa dalam penguasaan materi pelajaran.

b) Membangkitkan motivasi siwa untuk belajar.

c) Merangsang keingintahuan siswa terhadap sesuatu.

d) Memfokuskan siswa pada sesuatu yang diinginkan.

e) Membimbing siswa untuk menemukan atau menyimpulkan sesuatu.

f) Menyegarkan kembali pengetahuan siswa.

d. Masyarakat belajar (Learning Community)

Konsep masyarakat belajar dalam CTL, menyarankan agar hasil pembelajaran diperoleh melalui kerja sama dengan orang lain. Kerja sama itu dapat dilakukan dalam berbagai bentuk, baik dalam kelompok belajar secara formal maupun dalam lingkungan yang terjadi secara alamiah. Hasil belajar dapat diperoleh dari sharing dengan orang lain, antar teman, antar kelompok. Inilah hakikat dari masyarakat belajar, masyarakat yang saling berbagi pengalaman, informasi dan pengetahuan. Dalam kelas CTL, penerapan asas masyarakat belajar dapat dilakukan dengan menerapkan pembelajaran melalui kelompok. Kemudian guru dapat memberikan pendampingan dengan cara mendatangkan orang-orang yang memiliki keahlian di bidang tertentu yang sedang dibahas oleh siswa.

e. Pemodelan (Modelling)

12. http://fuadhasanscreen.blogspot.com/2012/01/strategi-pembelajaran-kontekstual.html Diakses Pada Tanggal 20 Desember 2019. 
Asas modelling adalah proses pembelajaran dengan memperagakan sesuatu sebagai contoh yang dapat ditiru oleh setiap siswa. Misalnya guru MI memberikan contoh tata cara berwudhu, atau guru olah raga memberikan contoh berenang. Proses modelling tidak terbatas dari guru saja, akan tetapi dapat juga guru memanfaatkan siswa yang dianggap memiliki kemampuan. Misalnya siswa yang mengetahui tata cara berwudhu disuruh memberikan contoh kepada siswa yang lain.

\section{f. Refleksi (Reflection)}

Refleksi adalah cara berfikir tentang apa yang baru dipelajari atau berfikir ke belakang tentang apa-apa yang sudah kita lakukan di masa lalu. ${ }^{13}$ Melalui proses refleksi, pengalaman belajar itu akan dimasukkan dalam struktur kognitif siswa pada akhirnya akan menjadi bagian dari pengetahuan yang dimilikinya. Bisa terjadi melalui proses refleksi siswa akan memperbarui pengetahuan yang telah dibentuknya atau menambah khazanah pengetahuannya. Dalam proses pembelajaran CTL, setiap berakhir proses pembelajaran, guru memberikan kesempatan kepada siswa untuk "merenung" atau mengingat kembali apa yang telah dipelajarinya. Biarkan secara bebas siswa menafsirkan pengalamannya sendiri, sehingga ia dapat menyimpulkan tentang pengalaman belajarnya.

g. Penilaian nyata (Authentic Assessment)

Penilaian nyata adalah proses yang dilakukan guru untuk mengumpulkan informasi tentang perkembangan belajar yang dilakukan siswa. Penilaian ini diperlukan untuk mengetahui apakah siswa benar-benar belajar atau tidak, memahami atau tidak, menguasai atau tidak, apakah pengalaman belajar siswa memiliki pengaruh yang positif terhadap perkembangan baik intelektual maupun mental siswa. Penilaian yang autentik dilakukan secara terintegrasi dengan proses pembelajaran. Penilaian ini dilakukan secara continue selama kegiatan berlangsung. Oleh sebab itu, tekanannya diarahkan kepada proses belajar bukan kepada hasil belajar. 


\section{Pembahasan}

Pembelajaran kotekstual ini dimana peserta didik akan belajar dengan baik jika apa yang dipelajari terkait dengan apa yang telah diketahui dan kegiatan yang akan terjadi di sekelilingnya. Pembelajaran ini menekankan pada daya pikir yang tinggi, transfer ilmu pengetahuan, mengumpulkan dan menganalisis data, memecahakan problema-problema tertentu baik secara individu maupun kelompok. ${ }^{14}$

Manfaat pembelajaran kontekstual (contextual teaching and learning) adalah konsep belajar yang membantu guru mengaitkan antara materi yang diajarkannya dengan situasi dunia nyata siswa dan mendorong siswa membuat hubungan antara pengetahuan yang dimilikinya dengan penerapannya dalam kehidupan mereka sehari- hari.

Pembelajaran dengan CTL akan memungkinkan proses belajar yang tenang dan menyenangkan karena proses pembelajaran dilakukan secara alamiah dan kemudian peserta didik dapat mempraktikkan secara langsung berbagai materi yang telah dipelajarinya. Pembelajaran CTL mendorong peserta didik memahami hakekat, makna dan manfaat belajar sehingga memberikan stimulus dan motivasi kepada mereka untuk rajin dan senantiasa belajar.

Dalam pembelajaran kontekstual tugas guru adalah memberikan kemudaahan belajar kepada peserta didik, dengan menyediakan berbagai sarana dan sumber belajar yang memadai. ${ }^{15}$ Guru bukan hanya menyampaikan materi pembelajaran yang berupa hafalan, tetapi mengatur lingkungan dan strategi pembelajaran yang memungkinkan peserta didik belajar. Lingkungan belajar yang kondusif sangat penting dan sangat menunjang pembelajaran kontekstual, dan keberhasilan pembelajaran secara keseluruhan.

Adapun model-model pembelajaran kontekstual yang dikemukakan oleh Kokom Komalasari, sebagai berikut :

a. Pembelajaran berbasis masalah (problem based learning)

Strategi pembelajaran menggunakan masalah dunia nyata sebagai sutu konteks bagi siswa untuk tentang berfikir kritis dan ketrampilan pemecahan masalah, serta memperoleh pengertahuan konsep yang esensi dari mata pelajaran. Contohnya : PBI (Problem Based Introduction), Debat, Isu kontroversial.

14. Khaeruddin dan Mahfud Junaedi, Kurikulum Tingkat Satuan Pendidikan ..........., Hlm. 200.

${ }^{15}$. E. Mulyasa, Implementasi Kurikulum 2004 Panduan Pembelajaran KBK, (Bandung: PT Remaja Rosdakarya, 2004) Hlm, 137. 
b. Pembelajaran kooperatif (cooperative learning)

Pembelajaran kooperatif merupakan strategi pembelajaran melaui kelompok kecil siswa yang saling bekerja sama dalam memaksimalkan kondisi belajar untuk mencapai tujuan belajar. Contohnya: Jigsaw (model tim ahli), team games tournament (TGT).

c. Model pembelajaran berbasis proyek (project- based learning)

Model pembelajaran ini menekankan pada pendekatan yang memuat prinsip dan konsep utama suatu disiplin, melibatkan siswa dalam memecahkan masalah dan tugas penuh makna lainya, mendorong siswa untuk bekerja mandiri membangun pembelajaran dan akhirnya menghasilkan karya nyata. Contohnya : pembelajaran portofolio, group investigation.

d. Model pembelajaran pelayanan (service learning)

Pembelajaran pelayanan menekankan pendekatan yang menyediakan suatu aplikasi praktis suatu pengembangan pengetahuan dan ketrampilan baru untuk kebutuhan di masnyarakat melaui proyek dan ativitas. Contohnya : bakti sosial, pengabdian kepada masnyarakat.

e. Model pembelajaran berbasis kerja.

Model pembelajaran berbasis kerja adalah suatu strategi pembelajaran yang memungkinkan siswa menggunakan konteks tempat kerja untuk mempelajari materi pelajaran berbasis sekolah dan bagaimana materi tersebut dipergunakan kembali di tempat kerja atau sejenisnya dan berbagai aktivitas dipadukan dengan materi pelajaran untuk kepentingan siswa. Contohnya : role playing, studi lapangan kerja.

f. Model pembelajaran konsep.

Setiap mata pelajaran mengandung muatan konsep-konsep yang harus dipahami siswa. Pendekatan kontekstual menghendaki konsp-konsep tersebut dikonstruk dan ditemukan oleh siswa sendiri melaui keterkaitanya dengan relaita kehidupan dan pengalaman siswa. disamping itu, hendaknya guru membelajarkan siswa memahami konsep - konsep secara aktif, kreatif, interaktif dan menyenangkan bagi siswa sehingga konsep mudah dipahami dan bertahan lama dalam stuktur kognitif siswa. ${ }^{16}$ Contohnya : Make-A Match (mencari pasangan).

Pembelajaran konstekstual mengarahkan siswa kepada proses pemecahan masalah, sebab dengan memecahkan masalah anak akan berkembang secara utuh, bukan hanya perkembangan intelektual tetapi juga mental dan emosionalnya. Belajar secara konstekstual

\footnotetext{
${ }^{16}$. Kokom Komalasari, Pembelajaran Kontekstual, ........., Hlm, 84.
} 
adalah belajar bagaimana anak menghadapi persoalan. Belajar adalah proses pengalaman sendiri yang berkembang secara bertahap dari sederhana menuju yang kompleks.

Sebagai sebuah strategi pembelajaran, pembelajaran kontekstual mempunyai keunggulan dan kelemahan dalam proses pelaksanaanya.

Adapun keunggulan dan kelemahan sebagai berikut $:{ }^{17}$

a. Keunggulan pembelajaran kontekstual :

1) Pembelajaran konstekstual mendorong siswa dapat menemukan hubungan antara materi yang dipelajari dengan situasi kehidupan nyata, artinya siswa dituntut untuk dapat menangkap hubungan antara pengalaman belajar di sekolah dengan kehidupan nyata siswa secara terintegrasi dan alamiah sehingga mampu menggali, berdiskusi, berpikir kritis, dan memecahkan masalah nyata yang dihadapinya dengan cara bersama-sama.

2) Pembelajaran konstekstual mendorong siswa untuk dapat menerapkannya dalam kehidupan, artinya siswa tidak hanya diharapkan dapat memahami materi yang dipelajarinya, akan tetapi bagaimana materi pelajaran itu dapat mewarnai perilaku/tingkah laku dalam kehidupan sehari-hari.

3) Pembelajaran konstekstual menekankan kepada proses keterlibatan siswa untuk menemukan materi, artinya proses belajar diorientasikan pada proses pengalaman secara langsung. Proses belajar dalam konteks CTL tidak mengharapkan agar siswa hanya menerima materi pelajaran, melainkan dengan cara proses mencari dan menemukan sendiri materi pelajaran.

b. Kelemahan pembelajaran kontekstual

1) Membutuhkan waktu yang lama bagi peserta didik untuk bisa memahami semua materi.

2) Guru lebih intensif dalam membimbing. Karena dalam metode CTL. Guru tidak lagi berperan sebagai pusat informasi. Tugas guru adalah mengelola kelas sebagai sebuah tim yang bekerja bersama untuk menemukan pengetahuan dan ketrampilan yang baru bagi siswa.

3) Guru memberikan kesempatan kepada siswa untuk menemukan atau menerapkan sendiri ide-ide dan mengajak siswa agar dengan menyadari dan dengan sadar

${ }^{17}$. http://fuadhasanscreen.blogspot.com/2012/01/strategi-pembelajaran-kontekstual.html Diakses Pada Tanggal 20 Desember 2019. 
menggunakan strategi-strategi mereka sendiri untuk belajar. Namun dalam konteks ini tentunya guru memerlukan perhatian dan bimbingan yang ekstra terhadap siswa agar tujuan pembelajaran sesuai dengan apa yang diterapkan semula.

\section{Faktor - Faktor yang Mempengaruhi Keberhasilan.}

1. Guru

Guru memiliki peran penting bagi proses pendidikan, guru sebagai ujung tombak dalam pelaksanaan pendidikan merupakan pihak yang sangat berpengaruh dalam proses pembelajaran. Kepiawaian dan kewibawaan guru sangat menentukan kelangsungan proses belajar mengajar di kelas ataupun efeknya di luar kelas. Guru harus pandai membawa siswanya kepada tujuan yang hendak dicapai.

Dalam pembaruan pembelajaran melalui pembelajaran kontekstual, keterlibatan guru mulai dari perencanaan inovasi pendidikan sampai pelaksanaan dan evaluasinya memainkan peranan yang sangat besar bagi keberhasilan inovasi pendidikan. Tanpa melibatkan mereka, maka sangat mungkin mereka menolak inovasi yang diperkenalkan kepada mereka.

2. Peserta didik

Sebagai subjek utama dalam pendidikan terutama dalam proses pembelajaran, siswa memegang peran penting yang sangat dominan. Dalam proses pembelajaran, siswa dapat menetukan keberhasilan belajar melalui pengunaan intelegensia, daya motorik, pengalaman, kemauan dan komitmen yang timbul dalam diri mereka tanpa adanya paksaan. Hal ini bisa terjadi apabila siswa juga dilibatkan dalam proses inovasi pembelajaran, walaupun hanya dengan mengenalkan kepada mereka tujuan dari perubahan itu, mulai dari perencanan sampai dengan pelaksanaan, sehingga apa yang mereka lakukan merupakan tanggung jawab bersama yang harus dilaksanakan dengan konsekuen.

3. Fasilitas

Fasilitas, termasuk sarana dan prasarana pendidikan, tidak bisa diabaikan dalam proses pendidikan khususnya dalam proses pembelajaran. Fasilitas, terutama fasilitas belajar mengajar merupakan hal yang esensial dalam mengadakan perubahan dan pembaruan proses pembelajaran. Misalnya ketersediaan media dan 
alat peraga pembelajaran, komputer dan internet, dan sebagainya.

4. Biaya

Inovasi pembelajaran kontekstual, sering kali dirasakan guru dan peserta didik membebani dengan berbagai media, sumber, tugas yang harus pula mengeluarkan biaya yang tidak sedikit, sehingga keterbatasan biaya, sedikit banyak akan menghambat pelaksanaan inovasi pembelajaran kontekstual. ${ }^{18}$

\section{Penutup}

Pembelajaran kontekstual atau (CTL) merupakan suatu konsep belajar dimana guru menghadirkan situasi dunia nyata ke dalam kelas dan mendorong siswa membuat hubungan antara pengetahuan yang dimilikinya dengan penerapannya dalam kehidupan mereka sebagai anggota keluarga dan masyarakat. Dengan konsep ini, hasil pembelajaran diharapkan lebih bermakna bagi siswa. Proses pembelajaran berlangsung lebih alamiah dalam bentuk kegiatan siswa bekerja dan mengalami, bukan transfer pengetahuan dari guru ke siswa.

Contextual teaching and learning (CTL) adalah suatu strategi pembelajaran yang menekankan kepada proses keterlibatan siswa secara penuh untuk dapat menemukan materi yang dipelajari dan menghubungkannya dengan situasi kehidupan nyata sehingga mendorong siswa untuk dapat menerapkannya dalam kehidupan mereka. Pada dasarnya, strategi pembelajaran kontekstual sangat menekankan dalam pengembangan 3 aspek, yaitu kognitif, psikomotorik dan afektif. Maka dari itu, sangatlah penting apabila peserta didik atau siswa diberikan ruang untuk terlibat di dalam kegiatan pembelajaran.

\section{Referensi}

Mulyasa, E, Kurikulum Tingkat Satuan Pendidikan, Bandung: PT Remaja Rosdakarya, 2007. , Menjadi Guru Profesioanal (Menciptakan Pembelajaran Kreatif dan Menyenangkan), Bandung: PT Remaja Rosdakarya, 2005.

, Implementasi Kurikulum 2004 Panduan Pembelajaran KBK, Bandung: PT Remaja Rosdakarya, 2004.

Johnson, Elaine B, Contextual Teaching \& Learning (Menjadikan Kegiatan Belajar-Mengajar

18. Kokom Komalasari, Pembelajaran Kontekstual, Hlm, 255. 
Mengasikkan dan Bermakna),Terj. Ibnu Setiawan, Bandung : Penerbit MLC, 2007.

Khaeruddin dan Mahfud Junaedi, Kurikulum Tingkat Satuan Pendidikan (Konsep dan Implementasinya di Madrasah), Yogyakarta : PILAR MEDIA, 2007.

Komalasari, Kokom, Pembelajaran Kontekstual: Konsep dan Aplikasi, Bandung : PT Refika Aditama, 2010.

Trianto, Mendesain Model Pembelajaran Inovatif- Progresif : Konsep, Landasan, dan Implementasinya Pada Kurikulum Tingkat Satuan Pendidikan (KTSP), (Jakarta : Prenada Media Group, 2010,

http://organisasi.org/strategi-pembelajaran-kontekstual-oleh-oleh-dari-plpg-slamet-p Diakses Pada Tanggal 20 Desember 2019.

http://fuadhasanscreen.blogspot.com/2012/01/strategi-pembelajaran-kontekstual.html Diakses Pada Tanggal 20 Desember 2019. 